\title{
WEIGHT AT THIRD BIRTHDAY RELATED TO BIRTH WEIGHT, DURATION OF GESTATION, AND BIRTH ORDER*
}

\author{
BY \\ C. R. LOWE and J. R. GIBSON \\ From the Department of Social Medicine, University of Birmingham
}

It is now well recognized that the weight of children during the first few years of life is closely related to their weight at birth. This point has been made by Illingworth in a number of publications (Illingworth, 1939 and 1950; Illingworth, Harvey, and Gin, 1949; Illingworth, Harvey and Jowett, 1950), and has been confirmed recently by Parfit (1951) and by Norval, Kennedy, and Berkson (1951). In general it appears that if infants are grouped according to birth weight, the mean weights of the groups retain the same order at least until the third birthday, and the differences between the groups remain not less than they were at birth.

Birth weight is directly related both to duration of gestation and to birth order. The studies mentioned above, however, ignore the possible influence of these two variables upon subsequent rate of growth, and it is the purpose of this communication to examine their influence upon weight at the third birthday.

\section{MATERIAL}

Data collected on all births $(23,970)$ delivered in Birmingham during 1947 have already been used in investigation of duration of gestation, birth weight, birth order, survival, etc. Birth weight and duration of gestation were recorded for 16,163 single births known to have survived the first year of life (Gibson and McKeown, 1951). For the present purpose the record cards of these births were sorted according to duration of gestation (four groups) and birth weight (eight groups), and samples were taken from each of these groups in such a way that the less common birth weights and durations of gestation were well represented (see Appendix, p. 82). Thus, in the birth weight group $5 \frac{1}{2}-6 \frac{1}{2} \mathrm{lb}$., the sample included all infants of less than 35 weeks, one-fifth of those of 35-38 weeks, one-tenth of those of 39-42 weeks, and all of 42 or more weeks gestation. The record cards carried consecutive identification numbers, which, so far as could be determined, were indepen-

* This research was assisted by a grant from the Birmingham University Students' Social Services Fund. dent of the variables under consideration, and a method which used the last two digits of these numbers was devised to ensure that the fractional samples were taken at random.

By this method we obtained the names and addresses of 2,302 infants of known birth date, birth weight, and duration of gestation, who were born alive in Birmingham during 1947. During 1950 one of two social workers attempted to visit each of these children within 10 days of the third birthday. At each successful visit the following information was recorded: unclad weight in pounds and ounces (taken on portable scales); standing height in inches (measured on a steel rule); duration of breas feeding and history of morbidity during the first 3 year of life (obtained from the mother).

Information was collected in this way for 1,782 (77 per cent.) of the sample of 2,302 children, and the analysis which follows is based on 927 boys and 855 girls of known birth weight and duration of gestation who were visited, weighed, and measured within 10 days of their third birthdays.

Weight at Third Birthday Related to Birth Weight and DURation of Gestation

In Table I (opposite) mean weights of male and female children at the third birthday are related to duration of gestation and birth weight. The mean weights of children in column and row totals have not been given, since the sampling procedure adopted makes this summation of doubtful value. Although unqualified means are not satisfactory summarizing indices of small numbers of rather widely dispersed measurements, the Table confirms the observation that third birthday weight is closely related to birth weight; for both sexes, mean weight at the third birthday increases by approximately one pound for each pound increase in weight at birth.

By the third birthday male children are, on the average, about one pound heavier than female children of the same birth weight. There is no very obvious association, however, between mean weight and duration of gestation. 
TABLE I

MEAN WEIGHT (lb.) AT THIRD BIRTHDAY RELATED TO BIRTH WEIGHT AND DURATION OF GESTATION

\begin{tabular}{|c|c|c|c|c|c|c|c|c|}
\hline \multirow[b]{3}{*}{ 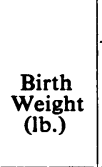 } & \multicolumn{8}{|c|}{ Duration of Gestation (wks) } \\
\hline & \multicolumn{4}{|c|}{ Males } & \multicolumn{4}{|c|}{ Females } \\
\hline & $<35$ & $35-38$ & $39-42$ & $\begin{array}{c}43 \\
\text { and } \\
\text { Over }\end{array}$ & $<35$ & $35-38$ & $39-42$ & $\begin{array}{c}43 \\
\text { and } \\
\text { Over }\end{array}$ \\
\hline$<4 \frac{1}{2}$ & $\begin{array}{l}30 \cdot 9 \\
(20)\end{array}$ & $\begin{array}{l}28 \cdot 5 \\
(17)\end{array}$ & $\begin{array}{c}29 \cdot 3 \\
(5)\end{array}$ & - & $\begin{array}{l}29 \cdot 5 \\
(20)\end{array}$ & $\begin{array}{l}27 \cdot 8 \\
(25)\end{array}$ & $\begin{array}{l}30 \cdot 8 \\
(10)\end{array}$ & 一 \\
\hline $4 \frac{1}{2}-$ & $\begin{array}{l}30 \cdot 8 \\
(27)\end{array}$ & $\begin{array}{l}30 \cdot 7 \\
(32)\end{array}$ & $\begin{array}{l}30 \cdot 0 \\
(21)\end{array}$ & $\begin{array}{l}29 \cdot 1 \\
(4)\end{array}$ & $\begin{array}{l}29 \cdot 6 \\
(29)\end{array}$ & $\begin{array}{r}30 \cdot 3 \\
(48)\end{array}$ & $\begin{array}{r}30 \cdot 0 \\
(43)\end{array}$ & $\begin{array}{r}27 \cdot 3 \\
(2)\end{array}$ \\
\hline $5 \frac{1}{2}-$ & $\begin{array}{l}33 \cdot 0 \\
(25)\end{array}$ & $\begin{array}{l}31 \cdot 6 \\
(44)\end{array}$ & $\begin{array}{l}31 \cdot 6 \\
(39)\end{array}$ & $\begin{array}{l}30 \cdot 4 \\
(22)\end{array}$ & $\begin{array}{l}30.4 \\
(26)\end{array}$ & $\begin{array}{l}30 \cdot 6 \\
(48)\end{array}$ & $\begin{array}{l}30 \cdot 8 \\
(63)\end{array}$ & $\begin{array}{l}30 \cdot 0 \\
(39)\end{array}$ \\
\hline $6 \frac{1}{2}-$ & $\begin{array}{l}31 \cdot 6 \\
(34)\end{array}$ & $\begin{array}{l}32.9 \\
(27)\end{array}$ & $\begin{array}{l}31 \cdot 8 \\
(38)\end{array}$ & $\begin{array}{l}32 \cdot 8 \\
(45)\end{array}$ & $\begin{array}{l}32 \cdot 3 \\
(25)\end{array}$ & $\begin{array}{l}31 \cdot 5 \\
(36)\end{array}$ & $\begin{array}{l}31 \cdot 5 \\
(47)\end{array}$ & $\begin{array}{l}31 \cdot 6 \\
(60)\end{array}$ \\
\hline $7 \frac{1}{2}-$ & $\begin{array}{l}33 \cdot 6 \\
(17)\end{array}$ & $\begin{array}{l}33 \cdot 7 \\
(53)\end{array}$ & $\begin{array}{l}34 \cdot 6 \\
(42)\end{array}$ & $\begin{array}{l}33 \cdot 5 \\
(68)\end{array}$ & $\begin{array}{l}32 \cdot 5 \\
(17)\end{array}$ & $\begin{array}{l}34 \cdot 5 \\
(37)\end{array}$ & $\begin{array}{l}32 \cdot 4 \\
(33)\end{array}$ & $\begin{array}{l}32 \cdot 7 \\
(51)\end{array}$ \\
\hline $8 \frac{1}{2}-$ & $\begin{array}{l}36 \cdot 7 \\
(9)\end{array}$ & $\begin{array}{r}34 \cdot 8 \\
(32)\end{array}$ & $\begin{array}{l}34 \cdot 7 \\
(102)\end{array}$ & $\begin{array}{l}34 \cdot 7 \\
(41)\end{array}$ & $\begin{array}{c}32 \cdot 9 \\
(2)\end{array}$ & $\begin{array}{l}33 \cdot 7 \\
(20)\end{array}$ & $\begin{array}{l}34 \cdot 2 \\
(59)\end{array}$ & $\begin{array}{l}33 \cdot 3 \\
(24)\end{array}$ \\
\hline $9 \frac{1}{2}-$ & $\begin{array}{l}36 \cdot 6 \\
(3)\end{array}$ & $\begin{array}{l}36 \cdot 3 \\
(25)\end{array}$ & $\begin{array}{l}34 \cdot 7 \\
(56)\end{array}$ & $\begin{array}{l}34 \cdot 4 \\
\text { (19) }\end{array}$ & $\begin{array}{l}32 \cdot 0 \\
(1)\end{array}$ & $\begin{array}{l}35 \cdot 6 \\
(9)\end{array}$ & $\begin{array}{l}33.4 \\
(32)\end{array}$ & $\begin{array}{l}34 \cdot 2 \\
(16)\end{array}$ \\
\hline $\begin{array}{c}10 \frac{1}{2} \\
\text { and Over }\end{array}$ & - & $\begin{array}{c}35 \cdot 5 \\
(4)\end{array}$ & $\begin{array}{l}37 \cdot 0 \\
(48)\end{array}$ & $\begin{array}{c}34 \cdot 2 \\
(8)\end{array}$ & - & $\begin{array}{c}36 \cdot 6 \\
(2)\end{array}$ & $\begin{array}{l}36 \cdot 3 \\
(24)\end{array}$ & $\begin{array}{c}32 \cdot 8 \\
(7)\end{array}$ \\
\hline
\end{tabular}

Numbers in brackets are numbers of children upon which means are based.

Since length at birth had not been recorded, we were unable to compare standing height with this measurement. Table II therefore makes the less satisfactory comparison between mean height and birth weight and duration of gestation. On the average, male children are a little taller than female children of the same birth weight. But when the sexes are considered separately, the third birthday measurement is again seen to be related to birth weight, and although the association is a little irregular, mean height increases fairly regularly with increasing birth weight.

TABLE II

MEAN LENGTH (in.) AT THIRD BIRTHDAY RELATED TO BIRTH WEIGHT AND DURATION OF GESTATION

\begin{tabular}{|c|c|c|c|c|c|c|c|c|}
\hline \multirow{3}{*}{$\begin{array}{c}\text { Birth } \\
\text { Weight } \\
\text { (lb.) }\end{array}$} & \multicolumn{8}{|c|}{ Duration of Gestation (wks) } \\
\hline & \multicolumn{4}{|c|}{ Males } & \multicolumn{4}{|c|}{ Females } \\
\hline & $<35$ & $35-38$ & $39-42$ & $\begin{array}{c}43 \\
\text { and } \\
\text { Over }\end{array}$ & $<35$ & $35-38$ & $39-42$ & $\begin{array}{c}43 \\
\text { and } \\
\text { Over }\end{array}$ \\
\hline$<4 \frac{1}{2}$ & $36 \cdot 7$ & $35 \cdot 7$ & $36 \cdot 7$ & - & $35 \cdot 6$ & $35 \cdot 4$ & $36 \cdot 1$ & - \\
\hline $4 \frac{1}{2}-$ & $36 \cdot 3$ & $36 \cdot 8$ & $36 \cdot 2$ & $34 \cdot 7$ & $36 \cdot 0$ & $36 \cdot 3$ & $36 \cdot 0$ & $34 \cdot 5$ \\
\hline $5 \frac{1}{2}-$ & $37 \cdot 5$ & $36 \cdot 7$ & $36 \cdot 7$ & $36 \cdot 0$ & $36 \cdot 3$ & $36 \cdot 5$ & $36 \cdot 5$ & $36 \cdot 2$ \\
\hline $6 \frac{1}{2}-$ & $36 \cdot 6$ & $37 \cdot 5$ & $37 \cdot 3$ & $37 \cdot 1$ & $36 \cdot 9$ & $36 \cdot 7$ & $36 \cdot 8$ & $36 \cdot 8$ \\
\hline $7 \frac{1}{2}-$ & $37 \cdot 4$ & $37 \cdot 5$ & $37 \cdot 5$ & $37 \cdot 3$ & $37 \cdot 2$ & $37 \cdot 4$ & $37 \cdot 0$ & $36 \cdot 8$ \\
\hline $8 \frac{1}{2}-$ & $37 \cdot 5$ & $37 \cdot 8$ & $37 \cdot 6$ & $37 \cdot 7$ & $37 \cdot 0$ & $38 \cdot 0$ & $37 \cdot 4$ & $37 \cdot 4$ \\
\hline $9 \frac{1}{2}-$ & $37 \cdot 5$ & $38 \cdot 1$ & $37 \cdot 8$ & $37 \cdot 3$ & $35 \cdot 5$ & $37 \cdot 3$ & $37 \cdot 2$ & $37 \cdot 4$ \\
\hline $\begin{array}{c}10 \frac{1}{2} \\
\text { and Over }\end{array}$ & - & $37 \cdot 0$ & $38 \cdot 3$ & $37 \cdot 5$ & - & $38 \cdot 5$ & $37 \cdot 9$ & 36.9 \\
\hline
\end{tabular}

The fact that mean weight at third birthday increases by about the same amount as the birth weight (Table I) suggests that mean increase in weight (difference between third birthday weight and birth weight) may be independent both of birth weight and of duration of gestation. This possibility is explored and confirmed in Table III. Indeed, in this Table there is so little association between mean weight increment and either birth weight or duration of gestation, that, in this instance, there can be no great objection to summing rows and columns. The mean increase in weight is then $25.4 \mathrm{lb}$. for males and $24 \cdot 6 \mathrm{lb}$. for females.

TABLE III

MEAN INCREASE IN WEIGHT (lb.) BY THIRD BIRTHDAY RELATED TO BIRTHWEIGHT AND DURATION OF GESTATION

\begin{tabular}{|c|c|c|c|c|c|c|c|c|}
\hline \multirow{3}{*}{$\begin{array}{c}\text { Birth } \\
\text { Weight }\end{array}$} & \multicolumn{8}{|c|}{ Duration of Gestation (wks) } \\
\hline & \multicolumn{4}{|c|}{ Males } & \multicolumn{4}{|c|}{ Females } \\
\hline & $<35$ & $35-38$ & $39-42$ & $\begin{array}{c}43 \\
\text { and } \\
\text { Over }\end{array}$ & $<35$ & $35-38$ & $39-42$ & $\begin{array}{c}43 \\
\text { and } \\
\text { Over }\end{array}$ \\
\hline$<4 \frac{1}{2}$ & $26 \cdot 3$ & $24 \cdot 5$ & $25 \cdot 4$ & 二 & $25 \cdot 9$ & $23 \cdot 8$ & $\overline{26 \cdot 8}$ & - \\
\hline $4 \frac{1}{2}-$ & $26 \cdot 0$ & $25 \cdot 6$ & $25 \cdot 1$ & $24 \cdot 0$ & $24 \cdot 9$ & $25 \cdot 2$ & $23 \cdot 8$ & $22 \cdot 0$ \\
\hline $5 \frac{1}{2}-$ & $27 \cdot 0$ & $25 \cdot 8$ & $25 \cdot 7$ & $24 \cdot 4$ & $24 \cdot 4$ & $24 \cdot 7$ & $24 \cdot 7$ & $23 \cdot 9$ \\
\hline $6 \frac{1}{2}-$ & $24 \cdot 8$ & $26 \cdot 0$ & $25 \cdot 0$ & $25 \cdot 6$ & $25 \cdot 5$ & $24 \cdot 6$ & $24 \cdot 7$ & $24 \cdot 7$ \\
\hline $7 \frac{1}{2}-$ & $25 \cdot 7$ & $26 \cdot 0$ & $26 \cdot 8$ & $25 \cdot 5$ & $25 \cdot 0$ & $26 \cdot 8$ & $24 \cdot 3$ & $24 \cdot 8$ \\
\hline $8 \frac{1}{2}-$ & $28 \cdot 3$ & $26 \cdot 3$ & $25 \cdot 7$ & $25 \cdot 8$ & $24 \cdot 0$ & $25 \cdot 1$ & $25 \cdot 3$ & $24 \cdot 3$ \\
\hline $9 \frac{1}{2}-$ & $27 \cdot 0$ & $26 \cdot 4$ & $24 \cdot 9$ & $24 \cdot 5$ & $23 \cdot 0$ & $25 \cdot 9$ & $23 \cdot 7$ & $24 \cdot 6$ \\
\hline $\begin{array}{c}10 \frac{1}{2} \\
\text { and OVer }\end{array}$ & - & $25 \cdot 9$ & $26 \cdot 0$ & $23 \cdot 2$ & - & $26 \cdot 0$ & $25 \cdot 7$ & $21 \cdot 0$ \\
\hline
\end{tabular}

To carry this point a little further, the relationship between third birthday weight and birth weight has been summarized by fitting lines to the raw data by the method of least squares (Table IV). The equations for all males $(y=1 \cdot 0 x+25 \cdot 3)$ and for all females $(y=1 \cdot 0 x+24 \cdot 6)$ again suggest that, whatever the birth weight, by the third birthday males had gained about $25 \frac{1}{2} \mathrm{lb}$. on the average and females about $24 \frac{1}{2} \mathrm{lb}$.

TABLE IV

EQUATIONS SHOWING RELATIONSHIP BETWEEN WEIGHT AT THIRD BIRTHDAY $(y)$ AND BIRTH WEIGHT $(x)$

\begin{tabular}{c|c|c}
\hline $\begin{array}{c}\text { Duration of } \\
\text { Gestation (wks) }\end{array}$ & Males & Females \\
\hline$<35$ & $y=0 \cdot 9 x+26 \cdot 7$ & $y=0 \cdot 9 x+25 \cdot 8$ \\
\hline $35-38$ & $y=1 \cdot 3 x+23 \cdot 8$ & $y=1 \cdot 3 x+23 \cdot 3$ \\
\hline $39-42$ & $y=1 \cdot 1 x+24 \cdot 7$ & $y=1 \cdot 1 x+24 \cdot 1$ \\
\hline 43 and Over & $y=1 \cdot 0 x+25 \cdot 4$ & $y=0 \cdot 9 x+25 \cdot 1$ \\
\hline All Durations & $y=1 \cdot 0 x+25 \cdot 3$ & $y=1 \cdot 0 x+24 \cdot 6$ \\
\hline
\end{tabular}




\section{Weight at Third Birthday Related to BirTH ORDER}

Most writers are agreed that birth weight increases with birth rank. McKeown and Gibson (1951) recorded the following mean birth weights for the 1947 Birmingham births:

\begin{tabular}{c|c|c|c|c|c}
\hline \multicolumn{1}{c|}{ Birth Rank } & 1 & 2 & 3 & $\begin{array}{l}4 \\
\text { and Over }\end{array}$ & Total \\
\hline $\begin{array}{l}\text { Mean Birth Weight } \\
\text { (lb.) } \ldots\end{array}$ & $\begin{array}{l}7.17 \\
\pm 0.01\end{array}$ & $\begin{array}{l}7.46 \\
\pm 0.02\end{array}$ & $\begin{array}{l}7.65 \\
\pm 0.03\end{array}$ & $\begin{array}{l}7.65 \\
\pm 0.03\end{array}$ & $\begin{array}{l}7.41 \\
\pm 0.01\end{array}$ \\
\hline
\end{tabular}

Examination of the present sample of the same births indicated that by the third birthday firstborn children had more than compensated for their initial handicap; it is shown in Table $\mathrm{V}$ that mean weight is higher for first than for later births (see also the Figure). This negative association between birth order and rate of growth is also seen in Table VI (opposite). The correlation between birth weight and birth order (duration of gestation held constant) is +0.23 for males and +0.24 for females; the correlation between third birthday weight and birth order (birth weight and duration of gestation held constant) is $-0 \cdot 17$ and $-0 \cdot 22$.

Table VI illustrates a number of other points. In the first place it confirms that weight at third birthday is highly correlated with birth weight (males +0.49 and females +0.50 , with duration of gestation and birth order held constant). Secondly, and perhaps of more interest, there is a small negative correlation (males -0.10 and females -0.07 ) between third birthday weight and duration of gestation, when birth weight and birth order are
TABLE V

MEAN WEIGHT (lb.) AT THIRD BIRTHDAY RELATED TO BIRTH WEIGHT AND BIRTH ORDER

\begin{tabular}{|c|c|c|c|c|c|c|}
\hline \multirow{3}{*}{$\begin{array}{c}\text { Birth } \\
\text { Weight } \\
\text { (lb.) }\end{array}$} & \multicolumn{6}{|c|}{ Birth Order } \\
\hline & \multicolumn{3}{|c|}{ Males } & \multicolumn{3}{|c|}{ Females } \\
\hline & 1 & 2 and & $\begin{array}{l}4 \text { and } \\
\text { Over }\end{array}$ & 1 & $2 \underset{3}{2}$ and & $\begin{array}{l}4 \text { and } \\
\text { Over }\end{array}$ \\
\hline$<4 \frac{1}{2}$ & $\begin{array}{l}29 \cdot 8 \\
(26)\end{array}$ & $\begin{array}{l}30 \cdot 7 \\
(9)\end{array}$ & $\begin{array}{c}28 \cdot 6 \\
(7)\end{array}$ & $\begin{array}{l}28 \cdot 9 \\
(22)\end{array}$ & $\begin{array}{l}29 \cdot 2 \\
(25)\end{array}$ & $\begin{array}{c}28 \cdot 2 \\
(8)\end{array}$ \\
\hline $4 \frac{1}{2}-$ & $\begin{array}{l}30 \cdot 7 \\
(36)\end{array}$ & $\begin{array}{l}30 \cdot 3 \\
(33)\end{array}$ & $\begin{array}{l}30 \cdot 4 \\
(15)\end{array}$ & $\begin{array}{l}29 \cdot 9 \\
(66)\end{array}$ & $\begin{array}{l}29 \cdot 5 \\
(40)\end{array}$ & $\begin{array}{l}28 \cdot 5 \\
(15)\end{array}$ \\
\hline $5 \frac{1}{2}-$ & $\begin{array}{l}31 \cdot 8 \\
(61)\end{array}$ & $\begin{array}{l}31.4 \\
(52)\end{array}$ & $\begin{array}{l}31 \cdot 3 \\
(15)\end{array}$ & $\begin{array}{l}31 \cdot 0 \\
(93)\end{array}$ & $\begin{array}{l}30 \cdot 4 \\
(57)\end{array}$ & $\begin{array}{l}28 \cdot 9 \\
(26)\end{array}$ \\
\hline $6 \frac{1}{2}-$ & $\begin{array}{l}32 \cdot 7 \\
(67)\end{array}$ & $\begin{array}{l}32 \cdot 2 \\
(57)\end{array}$ & $\begin{array}{l}30 \cdot 8 \\
(19)\end{array}$ & $\begin{array}{l}32 \cdot 0 \\
(79)\end{array}$ & $\begin{array}{l}31 \cdot 9 \\
(58)\end{array}$ & $\begin{array}{l}30 \cdot 4 \\
(30)\end{array}$ \\
\hline $7 \frac{1}{2}-$ & $\begin{array}{l}34 \cdot 9 \\
(59)\end{array}$ & $\begin{array}{l}33 \cdot 5 \\
(89)\end{array}$ & $\begin{array}{l}32 \cdot 6 \\
(31)\end{array}$ & $\begin{array}{l}33.9 \\
(48)\end{array}$ & $\begin{array}{l}32 \cdot 8 \\
(68)\end{array}$ & $\begin{array}{l}32 \cdot 2 \\
(22)\end{array}$ \\
\hline $8 \frac{1}{2}-$ & $\begin{array}{l}36 \cdot 4 \\
(55)\end{array}$ & $\begin{array}{l}34 \cdot 4 \\
(82)\end{array}$ & $\begin{array}{l}33 \cdot 8 \\
(46)\end{array}$ & $\begin{array}{l}34 \cdot 1 \\
(22)\end{array}$ & $\begin{array}{l}33 \cdot 8 \\
(59)\end{array}$ & $\begin{array}{l}33 \cdot 0 \\
(24)\end{array}$ \\
\hline $9 \frac{1-}{2}-$ & $\begin{array}{l}36 \cdot 2 \\
(18)\end{array}$ & $\begin{array}{l}35 \cdot 9 \\
(47)\end{array}$ & $\begin{array}{l}33 \cdot 5 \\
(38)\end{array}$ & $\begin{array}{c}35 \cdot 0 \\
(9)\end{array}$ & $\begin{array}{l}34 \cdot 0 \\
(29)\end{array}$ & $\begin{array}{l}33 \cdot 5 \\
(20)\end{array}$ \\
\hline $\begin{array}{l}10 \frac{1}{2} \\
\text { and Over }\end{array}$ & $\begin{array}{c}38 \cdot 9 \\
(6)\end{array}$ & $\begin{array}{l}37 \cdot 7 \\
(25)\end{array}$ & $\begin{array}{l}35 \cdot 0 \\
(29)\end{array}$ & $\begin{array}{c}40 \cdot 9 \\
\text { (2) }\end{array}$ & $\begin{array}{l}37 \cdot 2 \\
(12)\end{array}$ & $\begin{array}{l}34 \cdot 0 \\
(19)\end{array}$ \\
\hline
\end{tabular}

Birth order was unknown for six of the 1,782 children traced.

held constant. This is not apparent in Table $I_{\infty}$ of but it might be expected that for a given birt weight and birth order infants of short durations of. gestation would gain weight a little more rapidf than infants of longer durations of gestation. Finally, when birth weight is held constant, birth order and duration of gestation are inversely related. The correlation is small and, practically speaking, of little importance (males -0.07 and females $-0.02)$; a similar association has recently been reported by Karn and Penrose (1951).
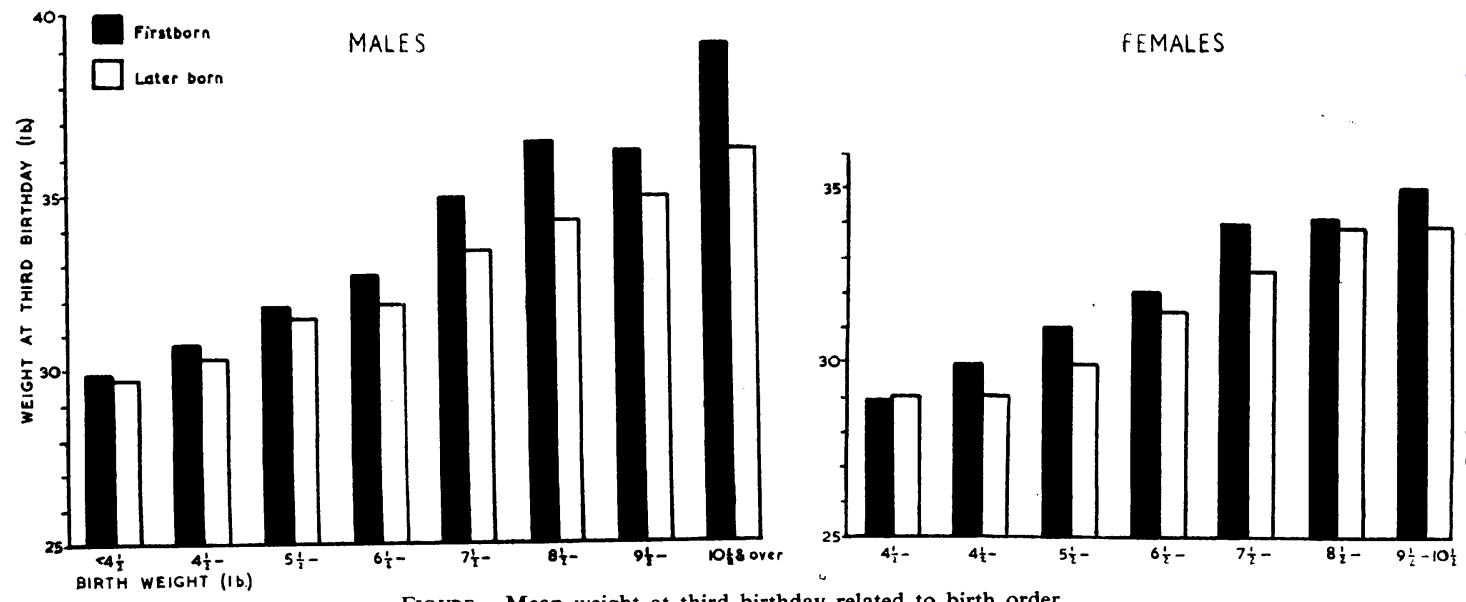

FIGURE.-Mean weight at third birthday related to birth order. 
TABLE VI

PARTIAL CORRELATION COEFFICIENTS (SHOWING ASSOCIATION BETWEEN WEIGHT AT THIRD BIRTHDAY BIRTH WEIGHT, DURATION OF GESTATION, AND BIRTH ORDER)

\begin{tabular}{|c|c|c|c|c|}
\hline \multirow{2}{*}{\multicolumn{2}{|c|}{$\begin{array}{l}\text { Correlated } \\
\text { Variables }\end{array}$}} & \multirow{2}{*}{$\begin{array}{l}\text { Variables } \\
\text { Held } \\
\text { Constant }\end{array}$} & \multicolumn{2}{|c|}{$\begin{array}{l}\text { Correlated } \\
\text { Coefficients }\end{array}$} \\
\hline & & & Males & Females \\
\hline $\begin{array}{l}\text { Weight } \\
\text { at third } \\
\text { birthday } \\
\text { and: }\end{array}$ & $\begin{array}{l}\text { (a) Birth weight } \\
\text { (b) Duration of } \\
\text { gestation } \\
\text { (c) Birth order }\end{array}$ & $\begin{array}{l}\text { Duration of ges- } \\
\text { tation and Birth } \\
\text { order } \\
\text { Birth weight } \\
\text { and Birth order } \\
\text { Birth weight and } \\
\text { Duration of ges- } \\
\text { tation }\end{array}$ & $\begin{array}{l}+0.49 \\
-0.10 \\
-0.17\end{array}$ & $\begin{array}{l}+0.50 \\
-0.07 \\
-0.22\end{array}$ \\
\hline $\begin{array}{c}\text { Birth } \\
\text { weight } \\
\text { and: }\end{array}$ & $\begin{array}{l}\text { (a) Duration of } \\
\text { gestation } \\
\text { (b) Birth order. }\end{array}$ & $\begin{array}{l}\text { Birth order } \\
\text { Duration of ges- } \\
\text { tation }\end{array}$ & $\begin{array}{l}+0.38 \\
+0.23 \\
\end{array}$ & $\begin{array}{r}+0.36 \\
+0.24 \\
\end{array}$ \\
\hline $\begin{array}{l}\text { Duration } \\
\text { of } \\
\text { gestation } \\
\text { and: }\end{array}$ & Birth order & Birth weight & -0.07 & -0.02 \\
\hline
\end{tabular}

\section{Discussion}

Two points of interest arise out of this inquiry. The first is that rate of post-natal growth is relatively independent of duration of gestation although it is closely related to weight at birth. Parfit (1951) has recently reported that weight increment (actual amount of weight gained since birth) is a function of sex but not of birth weight, and has suggested that in welfare clinics weight increment might be plotted on a chart on which birth weight is recorded as zero, and the expected range of values for weight increments indicated by a zone. Our own observations also suggest that this would be an improvement on the current practice of plotting weight against a so-called normal weight curve. The procedure in effect would standardize for variation in rate of growth attributable to variation in birth weight. But the difficulty of interpreting individual departures from a growth curve derived from mean values in a mixed population would remain.

The second point of interest is the association between rate of post-natal growth and birth order. It is well recognized that birth weight increases with birth order, and since there is no reason to suppose that genetic constitution is related to birth rank, this association must be attributable to differences in the pre-natal environment. But we have shown that the pre-natal growth rates of first and later births are reversed after birth, so that by the third birthday, weight is inversely related to birth rank. This change must be attributable to differences in the post-natal environment, and it is easy to suggest examples of post-natal influences related to family size which might be expected to have an effect on a child's rate of growth. For example the economic circumstances of families are closely related to the number of children, and the incidence of infection in the first year of life rises sharply with birth order (Gibson and McKeown, 1952).

\section{SUMmarY}

For 927 boys and 855 girls of known birth date, birth weight, and duration of gestation, weight and standing height were recorded within 10 days of the third birthday.

Mean weight at the third birthday was closely related to birth weight; the correlation between these variables, when duration of gestation and birth order were held constant, was +0.49 for males, and +0.50 for females.

There was no obvious association between mean weight at third birthday and duration of gestation, but there was a small negative correlation between third birthday weight and gestation when birth weight and birth order were held constant.

The relationship between third birthday weight and birth weight was summarized by fitting lines to the raw data by the method of least squares. The result $(y=1 \cdot 0 x+25 \cdot 3$ for males, and $y=1 \cdot 0 x+24 \cdot 6$ for females) suggested that, on the average, whatever the birth weight or duration of gestation, males had gained about $25 \frac{1}{2} \mathrm{lb}$. and females about $24 \frac{1}{2} \mathrm{lb}$. by the third birthday.

Weight at birth increased with birth order, but by the third birthday firstborn children of all birth weights were heavier, on the average, than children of higher birth ranks. The correlation between birth weight and birth order (duration of gestation held constant) was +0.23 for males, and +0.24 for females; between the third birthday weight and birth order (birth weight and duration of gestation held constant) the correlation was -0.17 for males, and -0.22 for females.

We gratefully acknowledge our indebtedness to Mrs. $\mathbf{M}$. Hopper and Miss M. Smith, who visited, weighed and measured all the children included in this survey.

\section{REFERENCES}

Gibson, J. R., and McKeown, T. (1951). British Journal of Social Medicine, 5, 177.

Medicine, (1952). Ibid., 6, 183.

Illingworth, R. S. (1939). Arch. Dis. Childh., 14, 121.

- (1950). Brit. Med. J., 1,96.

- Harvey, C. C., and G̈in, S-Y. (1949). Lancet, 2, 598.

- Harvey, C. C., and Gin, S-Y. (1949). Lancet, 2, 598. 380

Karn, M. N., and Penrose, L. S. (1951). Ann. Eugen., 16, 147.

McKeown, T., and Gibson, J. R. (1951). British Journal of Social Medicine, 5, 98. Norval, M., Kennedy, R. L. J., and Berkson, J. (1951). Hum. Biol.,
23, 273 .

Parfit, J. (1951). British Journal of Social Medicine, 5, 1. 
APPENDIX

DETAILS OF SAMPLE SELECTED FROM 16,163 SINGLE BIRTHS OF KNOWN BIRTH WEIGHT AND DURATION OF GESTATION DELIVERED IN BIRMINGHAM DURING 1947

\begin{tabular}{|c|c|c|c|c|c|c|c|c|c|c|c|c|c|c|c|c|}
\hline \multirow{3}{*}{$\begin{array}{c}\text { Birth } \\
\text { Weight } \\
\text { (lb.) }\end{array}$} & \multicolumn{16}{|c|}{ Duration of Gestation (wks) } \\
\hline & \multicolumn{4}{|c|}{$<35$} & \multicolumn{4}{|c|}{$35-38$} & \multicolumn{4}{|c|}{$39-42$} & \multicolumn{4}{|c|}{43 and Over } \\
\hline & $\begin{array}{c}\text { Num- } \\
\text { ber } \\
\text { of } \\
\text { births }\end{array}$ & $\begin{array}{l}\text { Sam- } \\
\text { pling } \\
\text { frac- } \\
\text { tion }\end{array}$ & $\begin{array}{l}\text { Percen- } \\
\text { tage } \\
\text { of } \\
\text { sample } \\
\text { traced }\end{array}$ & $\begin{array}{l}\text { Num- } \\
\text { ber } \\
\text { traced }\end{array}$ & $\begin{array}{l}\text { Num- } \\
\text { ber } \\
\text { of } \\
\text { births }\end{array}$ & $\begin{array}{l}\text { Sam- } \\
\text { pling } \\
\text { frac- } \\
\text { tion }\end{array}$ & $\begin{array}{l}\text { Percen- } \\
\text { tage } \\
\text { of } \\
\text { sample } \\
\text { traced }\end{array}$ & $\begin{array}{c}\text { Num- } \\
\text { ber } \\
\text { traced }\end{array}$ & $\begin{array}{c}\text { Num- } \\
\text { ber } \\
\text { of } \\
\text { births }\end{array}$ & $\begin{array}{l}\text { Sam- } \\
\text { pling } \\
\text { frac- } \\
\text { tion }\end{array}$ & $\begin{array}{l}\text { Percen- } \\
\text { tage } \\
\text { of } \\
\text { sample } \\
\text { traced }\end{array}$ & $\begin{array}{c}\text { Num- } \\
\text { ber } \\
\text { traced }\end{array}$ & $\begin{array}{c}\text { Num- } \\
\text { ber } \\
\text { of } \\
\text { births }\end{array}$ & $\begin{array}{c}\text { Sam- } \\
\text { pling } \\
\text { frac- } \\
\text { tion }\end{array}$ & \begin{tabular}{|} 
Percen- \\
tage \\
of \\
sample \\
traced
\end{tabular} & $\begin{array}{c}\text { Num- } \\
\text { ber } \\
\text { traced }\end{array}$ \\
\hline$<4 \frac{1}{2}$ & 59 & 1 & 68 & 40 & 52 & 1 & 81 & 42 & 21 & 1 & 71 & 15 & - & - & - & - \\
\hline $4 \frac{1}{2}-$ & 73 & 1 & 77 & 56 & 214 & 0.5 & 75 & 80 & 181 & 0.5 & 70 & 64 & 10 & 1 & 60 & 6 \\
\hline $5 \frac{1}{2}-$ & 68 & 1 & 75 & 51 & 670 & 0.2 & 74 & 92 & 1,380 & $0 \cdot 1$ & 81 & 102 & 98 & 1 & 62 & 61 \\
\hline $6 \frac{1}{2}-$ & 87 & 1 & 68 & 59 & 990 & $0 \cdot 1$ & 75 & 63 & 4,145 & $\overline{0.02}$ & 91 & 85 & 292 & 0.5 & 72 & 105 \\
\hline $7 \frac{1}{2}-$ & 48 & 1 & 71 & 34 & 574 & 0.2 & 73 & 90 & 4,236 & 0.02 & 95 & 75 & 316 & 0.5 & 78 & 119 \\
\hline $8 \frac{1}{2}-$ & 12 & 1 & 92 & 11 & 158 & 0.5 & 78 & 52 & 1,666 & $0 \cdot 1$ & 85 & 161 & 148 & 0.5 & 78 & 65 \\
\hline $9 \frac{1}{2}-$ & 5 & 1 & 80 & 4 & 51 & 1 & 63 & 34 & 465 & $0 \cdot 2$ & 80 & 88 & 46 & 1 & 76 & 35 \\
\hline $10 \frac{1}{2}-$ & - & - & - & - & 7 & 1 & 86 & 6 & 73 & 1 & 99 & 72 & 18 & 1 & 83 & 15 \\
\hline
\end{tabular}

It is regretted that a misprint occurred in Equation (vii) on p. 19 of the January issue of the Journal in the article on "Mortality from Tumours of the Urinary Bladder", by R. A. M. Case. Equation (vii) should read:

$R(Z . w . X)=[$ Anti-probit $Y(b . Z . X)][0.5483+0.00178 Z+0.0119(w-1935)] \div 100$ 